\title{
Proceedings
}

\section{Therapeutic functions of forests and green areas with regard to the universal potential of sensory gardens ${ }^{+}$}

\author{
Sandra Wajchman-Świtalska ${ }^{1,}{ }^{*}$, Alina Zajadacz ${ }^{2}$ and Anna Lubarska ${ }^{2}$ \\ 1 University of Life Sciences in Poznań, Faculty of Forestry and Wood Technology, Department of Forestry \\ Management, Wojska Polskiego St. 71C, 60-625 Poznań, Poland; sandra.switalska@up.poznan.pl \\ 2 Adam Mickiewicz University in Poznan, Faculty of Geographic and Geological Sciences \\ Chair of Tourism and Recreation, ul. Boguslawa Krygowskiego 10, 61-680 Poznan, Poland; \\ alina@amu.edu.pl (A.Z.); anna.lubarska@amu.edu.pl (A.L.). \\ * Correspondence: sandra.switalska@up.poznan.pl \\ † Presented at the 1st International Electronic Conference on Forests, 15-30 November 2020; \\ Available online: https://sciforum.net/conference/IECF2020
}

Published: 25 October 2020

\begin{abstract}
In the category of green areas which on a small area intensify feelings are sensory gardens. They also have great potential for eliminating stress symptoms and stimulating sensory feelings among people with disability. Sensory gardens, being an element of universal recreational development in urban and suburban conditions, can perfectly fulfill social, educational and therapeutic functions. Their distinguishing feature is a strong influence on non-visual senses. The space adapted to the needs of people with disability gives a sense of security, provide greater independence, can be used for passive and active therapy, and constitute a zone of social inclusion. Sensory gardens can be considered as an example of a comprehensive development of green areas that meets the requirements of universal design.

The presented study is a review. The authors show that providing urban communities a therapeutic contact with nature through the use of urban forests is a very important aspect of improving the quality of life. Special attention was paid to the potential of sensory gardens in the designing of recreational development which may be an opportunity to reduce the process of social exclusion of people with disability in the local environment.
\end{abstract}

Keywords: urban forests; forest therapy; urban environment; sensory gardens; wellbeing; social inclusion; recreational development; universal design

\section{Introduction}

A significant part of the world's population lives in urban areas, where there are many stressors [1]. Studies show that the less green in the neighbourhood, the higher level of cortisol, the "stress hormone", in the blood of residents [2]. The health benefits of contact with nature has been widely researched. They are described, among others, by "Nature Therapy Theory" [3,4]. One example of this form of therapy is forest bathing, also known as shinrin-yoku, a practice that combines a series of outdoor exercises and tasks based on mindfully using all five senses. There are also "Therapeutic landscapes", which are places that for various reasons can have a beneficial effect on health and wellbeing [5]. Moreover, a positive impact on behaviour and interpersonal self-improvement has "Wilderness therapy". This therapy combines experiential education, individual and group therapy with adventure-based therapy in a wildlife environment. Research show that physical activity in the natural environment is preferable to physical activity in a closed space in terms of the feeling of relaxation, well-being, reduction of stress and aggression [6]. Furthermore, the therapeutic properties 
of various plant communities have a wide range of impact on specific medical aspects, including disinfection, blood pressure lowering, anti-asthma, or immune-boosting etc. [7]. Factors in the forest environment that may provide health benefits include the aroma of plants, light intensity, humidity, wind, temperature, and oxygen concentrations [8].

The location of forests within or near the administrative boundaries of cities promote intensive recreational use of the forest environment. Thus, these areas can be an excellent places for citydwellers to provide health support. Furthermore, increasing outdoor recreation can be considered beneficial both on an individual level and to society as a whole [9]. For people living in large and dense cities urban green space plays an important social integrative role [10,11]. Unfortunately, the potential of natural settings in contributing to the quality of working and housing environments, which could enhance the health and well-being of residents is not fully considered in the current trend of building compact cities [12]. The aim of our study is to show that designing sensory gardens as one of the many elements of forest recreational development is an interesting form of diversifying the infrastructure.

\section{Universal design in sensory gardens - application in forests}

The relationships between people and the natural environment seems to be decidedly complex. The impact on humans health is varied depending on the plant community. In terms of biotherapeutic and psychoregulation pine forests are the most functional community. Volatile substances, apart from their strong disinfecting effect, lower blood pressure and affect the nervous system. For this reason, a longer stay in such forests, especially on hot and windless days, is contraindicated among elderly people, with low blood pressure and prone to migraines. For people of all ages and of varying health status suitable are mixed forests, acidophilous oak forests, and beechwood forests. These are plant communities that are universal in terms of biotherapeutic and psycho-regulatory. A favourable bioclimate also prevails in the woodlands along the banks of streams or rivers where the proximity of waters and intensive air exchange favour the stimulation of the body's immunity. The oak-hornbeam bioclimate is the opposite of the coniferous forests climate. It has a stimulating effect, strengthens the body's immunity, improves blood circulation, and increases blood pressure by narrowing peripheral vessels. As a result, a longer stay in such a forest is forbidden to people with hypertension, hyperthyroidism and those in a state of strong emotional agitation [7]. Knowledge of the health properties of plant communities is valuable for the planning of recreational infrastructure, in particular for facilities such as camping sites, recreation centres, sanatoriums, sports areas, playgrounds, forest kindergartens, and sensory gardens.

A sensory garden is 'a self-contained area that concentrates a wide range of sensory experiences. If designed well it provides a valuable resource for a wide range of uses, from education to recreation' [13]. Forests are neither self-contained, nor designed in the same way as gardens can be; what attracts people to the forest and also contributes to its therapeutic function is the feeling of communion with wild and untouched nature. In fact, there is careful forest management involved and some of the solutions can be easily transplanted from gardens to forests. There is one important factor that needs to be taken into account before any space is made physically accessible to anyone: the first barrier is the information, or rather the insufficient information, or even the lack of information altogether. Nowadays, online information on barrier-free infrastructure is crucial, and the website must comply with WCAG 2.0 guidelines and rules. This allows a visitor with disability to make an informed decision to visit a given place, and it applies to natural areas as well as to any other place [14].

First of all, in most sensory gardens their characteristic trait is their zonality. Usually the zones are created basing on the influence on human senses (e.g. "the zone of smell" or "the zone of taste") or human activity (e.g. "relax zone") [15]. It would be impractical to create artificial zones in forests in order to enhance the visitors' sensory experience; however, it seems feasible to alternate between different zones based on the level of activity. Resting places, equipped with benches and picnic tables of appropriate height, would be a place for spending time together and for passive rest. Wellprepared trails would serve for active recreation. 
Secondly, the design of the paths should be carefully considered. In sensory gardens the users prefer to stroll on one pathway, which links the zones together [16], rather than wander the net of paths. In the forest it would be recommended to mark the main route very clearly and put the majority of information boards, artificial toys and attractions, as well as any points of interest along it. There was a research conducted in Poland, Czech Republic and Slovakia, which showed, that the preferred spacing between recreational facilities in the forest is $200-500 \mathrm{~m}$. The length of the recreational path for people with disabilities, especially the wheelchair users, should not exceed 4 $\mathrm{km}$, unless an electric wheelchair is used, which allows for a larger length. What regards the surface, in general a stable, hardened, non-slip surface, integrated into the natural environment is considered the most wheelchair-friendly one (wood can be slippery, when wet, and different kinds of stone have their disadvantages) [17]. Hardened forests paths is quite a serious interference, though varied solutions can also be applied, depending on local conditions.

Thirdly, there is one more possibility, namely a sensory garden created in a forest, as a separate space, which uses the surroundings, as well as a "forest theme", to educate and entertain people with any disability or without it. Such places have been created i.e. in Poland and have been approved by the target group [18].

\section{Conclusions}

Beneficial effects of forest environment on human health and well-being are well-known. The issue of the development of recreational infrastructure is of key importance, bearing in mind the areas close to the population centers. The universal design application solves not only the technical problems of the recreational use of forests but also the problem of social exclusion. Sensory gardens have a great universal potential to be a part of planned recreational development. They can be applied within forest environment as well as other green areas. Apart from the known therapies based on contact with nature, they are another multisensory alternative.

\section{Supplementary Materials: -}

Author Contributions: Organization, S.W-Ś., A.Z. and A.L. ; implementation, S.W-Ś., A.Z. and A.L.; writing, S.W-Ś., A.Z. and A.L.; review and editing, S.W-Ś., A.Z. and A.L. All authors have read and agreed to the published version of the manuscript.

Funding: This work received no external funding.

Acknowledgments: The authors would like to thank all individuals and institutions who have so far been involved in their research on sensory gardens. Thanks to their valuable comments and observations, many phenomena have gained a broader and more complex background.

Conflicts of Interest: The authors declare no conflict of interest.

\section{References}

1. Vlachokostas, C., Banias, G., Athanasiadis, A., Achillas, C., Akylas, V., Moussiopoulos, N. Cense: a tool to assess combined exposure to environmental health stressors in urban areas. Environ. Int. 2014, 63, 1-10.

2. Roe, J.J.; Thompson, C.W.; Aspinall, P.A.; Brewer, M.J.; Duff, E.I.; Miller, D.; Mitchell, R.; Clow, A. Green Space and Stress: Evidence from Cortisol Measures in Deprived Urban Communities. Int. J. Environ. Res. Public Health 2013, 10, 4086-4103.

3. Miyazaki, Y., Park, B.J., Lee, J., 2011. Nature therapy, in designing our future. In Local Perspectives on Bioproduction, Ecosystems and Humanity, Osaki, M., Braimoh, A., Nakagami, K., Eds.; United Nations University Press: Tokyo, Japan, 2011; vol. 2011, pp. 407-412.

4. Song, C., Ikei, H., Kobayashi, M., Miura, T., Li, Q., Kagawa, T., Kumeda, S., Imai, M., Miyazaki, Y. Effects of viewing forest landscape on middle-aged hypertensive men. Urban For. Urban Green 2017, 21, 247-252.

5. Bell, S.L., Foley, R., Houghton, F., Maddrell, A., Williams, A.M. From therapeutic landscapes to healthy spaces, places and practices: A scoping review, Social Science and Medicine 2018, 196, 123-130. 
6. Thompson Coon, J., Boddy, K., Stein, K., Whear, R., Barton, J., Depledge, M.H. Does Participating in Physical Activity in Outdoor Natural Environments Have a Greater Effect on Physical and Mental Wellbeing than Physical Activity Indoors? A Systematic Review, Environmental Science E Technology 2011, 45(5), 1761-1772.

7. Krzymowska-Kostrowicka, A. Geoekologia turystyki i wypoczynku. Wydaw. Naukowe PWN: Warsaw, Poland, 1997, pp. 1-239.

8. Loureiro G, Rabaca MA, Blanco B, et al. Urban versus rural environment--any differences in aeroallergens sensitization in an allergic population of Cova da Beira, Portugal? Eur Ann Allergy Clin Immunol, 2005; 37(5), 187-93.

9. Eriksson, L., Nordlund, A. How is setting preference related to intention to engage in forest recreation activities? Urban Forestry and Urban Greening 2013,12(4),481-489.

10. Dwyer, J., Schroeder H., Gobster, P. The significance of urban trees and forests: toward a deeper understanding of values. Journal of Arboriculture 1991, 17, 276-284.

11. Germann-Chiari, C., Seeland, K. Are urban green spaces optimally distributed to act as places for social integration?. Results of a geographical information system (GIS) approach for urban forestry research. Forest Policy and Economics 2004, 6, 3-13

12. Tsunetsugu, Y., Lee, J., Park, B., Tyrväinen, L., Kagawa, T., Miyazaki, Y. Physiological and psychological effects of viewing urban forest landscapes assessed by multiple measurements. Landscape and Urban Planning 2013, 113, 90-93.

13. Sensory Trust. Sensory garden design advice http://www.sensorytrust.org.uk/information/factsheets/sensory-garden-4.html (accessed May 25, 2018).

14. Hennig, S.; Sattler, T.; Wasserburger, M.; Wasserburger, W. W. How to Improve Accessibility of Natural Areas: About the Relevance of Providing Information on Accessible Services and Facilities in Natural Areas Sabine Hennig, Thomas Sattler, Maria Wasserburger, Wolfgang W. Wasserburger. 2015, 2 (May), $803-812$.

15. Вукович (Vukovic), Н. А. (Natalya). Сенсорные Cadbl: Теория До Практика (Sensory Gardens: Theory and Practice); издательские решение: Санкт-Петербург, 2019.

16. Hussein, H. Sensory Gardens: Assessing Their Design and Use Publishing for a Sustainable Future. Intell. Build. Int. Earthscan 2010, 20035, 116-123. https://doi.org/10.3763/inbi.2010.0035.

17. Janeczko, E.; Jakubisová, M.; Woźnicka, M.; Fialova, J.; Kotásková, P. Preferences of People with Disabilities on Wheelchairs in Relation to Forest Trails for Recreational in Selected European Countries. Folia For. Pol. Ser. A 2016, 58 (3), 116-122. https://doi.org/10.1515/ffp-2016-0013.

18. Ogonowska-Chrobrowska, H.; Jakubowski, M. „las Widziany Dotykiem” - Integracyjny Leśny Ogród Edukacyjny w Nadleśnictwie Sieraków. Stud. i Mater. CEPL w Rogowie 2010, 1 (24), 165-172.

(c) 2020 by the authors; licensee MDPI, Basel, Switzerland. This article is an open access article distributed under the terms and conditions of the Creative Commons Attribution (CC-BY) license (http://creativecommons.org/licenses/by/4.0/). 